\title{
TAXONOMY AND ECOLOGY OF ECTOMYCORRHIZAL MACRO- FUNGI OF GRAND TETON NATIONAL PARK
}

\author{
Kent H. McKnight \\ Biosystematics and Beneficial Insects Institute \\ Agricultural Research Service \\ U.S. Department of Agriculture \\ Beltsville, MD \\ Kimball T. Harper \\ Brigham Young University \\ Provo, UT \\ and \\ Karl B. McKnight \\ St. Lawrence University \\ Canton, NY
}

\section{Objectives}

The research underway is directed toward 3 primary objectives. The first is to. inventory and document the presence of the species of macrofungi growing in Grand Teton National Park and environs. Detailed descriptions are written for new and uncommon species. A second objective is to appraise the role of macrofungi in the Park ecosystem and the third is to prepare keys, illustrations, and descriptions for as many species as possible.

\section{Methodology and Results}

No field studies were carried out in the Parks during 1985 but significant progress was made toward Objectives 1 and 2 above through continued work on previously collected specimens and data in two areas:

1. Taxonomic work on collections made earlier included use of thin-layer chromatography, SEM, and modern statistical analyses. Critical study of species of the ectomycorrhizal genus Cortinarius Fr. Subgenus Leprocybe Mos. are reported in a manuscript now in preparation which will be the first report on Leprocybe for North America. Previously species of this subgenus have been included in Section Telamonia or Inoloma of Cortinarius or in the genus Gymnopilus.

The following species of Cotinarius Subgen. Leprocybe not previously reported from Wyoming are added to the species inventory of the area: $C$. callisteus Fr., C. flavobasalis ined., C. subalpinus ined., C. zinziberatus Fr. var. longipes ined. Cortinarius renidens Fr. was found to be the same fungus as that reported by 
A merican authors as Gymnopilus terrestris Hesler.

This subgenus of Cortinarius contains the highly toxic and dangerous $\mathrm{C}$. orellanus (Fr.) which, although not yet reported from the Park area, is to be expected there as it has been found in the Uinta Mts. of Utah and Wyoming and from the Pacific Northwest. Other Leprocybes previously reported from the study area include Cortinarius ahsii McKn., C. gentilis (Fr.) Fr., and C. raphanoides (Fr.) Fr., making a total of 12 from the study area.

2. Further analysis of fungus tissue Cation Exchange Capacity (CEC) used the same methodology as in the previous report (McKnight, Harper, \& McKnight, 1985). The preliminary results of mineral and CEC analyses for soils and fungi suggested that differences in mineral cation uptake between species of fungi were due to differences in cell wall CEC. To establish that the CEC differences between fungal species which we had noted were not due simply to CEC differences in the associated soils, additional fungus specimens of each of the 18 species were analyzed, these having been taken from different sites. Although the second set of analyses are not all completed the results to date do not show a significant difference in fungal cell wall CEC values in samples of the same species from two different soils. This lends support to the hypothesis that CEC is a species characteristic not strongly modified by local environment.

Wacquant (1977), Woodward, Harper, and Tiedemann (1984), and others have estabilished that vascular plant root selectivity in cation absorption is governed by rootlet $\mathrm{CEC}$. Inasmuch as rootlets are frequently encased in mycorrhizal fungal hyphae, our data demonstrating that fungal cell-wall CEC is a species characteristic and not a function of local soil conditions suggests a fundamental explanation of the mechanism of selective. mineral uptake by plants. This leads to the further suggestion that one could propagate tissue of a selection of ectomycorrhizal fungal species and through use of sterile cultures for tree seedlings form known mycorrhizal partnerships that are able to optimize uptake of specific ions.

\section{Literature Cited}

McKnight, K. H., K. T. Harper, \& K. B. McKnight. 1985. Taxonomy and ecology of ectomycorrhizal macrofungi of Grand Teton National Park. In Univ. of W Y-Nat'l. Park Serv. Eighth Ann. Rept., 1984. pp. 51-61.

Wacquant, J. P. 1977. Physiocochemical selectivity for cations and CEC of grass Roots. Plant and Soil. 47:257-262.

Woodward, R. A., K. T. Harper, \& A. R. Tiedemann. 1984. An ecological consideration of the significance of cation-exchange capacity of roots of some Utah range plants. Plant and Soil. 79:169-180. 